(C) 2021, The Authors. Published by Elsevier Inc. and Fass Inc. on behalf of the American Dairy Science Association ${ }^{\circledR}$. This is an open access article under the CC BY-NC-ND license (http://creativecommons.org/licenses/by-nc-nd/4.0/).

\title{
Incorporation of the grazing utilization subindex and new updates to the Pasture Profit Index
}

\author{
T. Tubritt, ${ }^{1,2} \odot$ L. Shalloo, ${ }^{1} \odot$ T. J. Gilliland, ${ }^{2} \odot$ N. McHugh, ${ }^{1}$ and M. O'Donovan ${ }^{1 *}$ \\ ${ }^{1}$ Teagasc, Animal and Grassland Innovation Centre, Moorepark, Fermoy, Co. Cork, Ireland P61C996 \\ ${ }^{2}$ The Institute for Global Food Security, Queen's University Belfast, Belfast, N. Ireland BT9 5DL
}

\section{ABSTRACT}

Grazing efficiency has been shown to differ between perennial ryegrass varieties. Such differences affect the utilization of grass within grazing systems, influencing the profitability of grass-based ruminant production systems. The Pasture Profit Index (PPI) is an economic merit grass variety selection tool developed to identify varieties with the greatest economic potential for grassbased dairy production systems. A new grass utilization subindex was developed and incorporated into the PPI to identify varieties with superior grazing efficiency. The subindex rewards varieties with superior grazing efficiency, measured as residual grazed height, as these varieties allow increased amounts of herbage dry matter to be used by grazing animals. The economic values of all other traits within the PPI were reviewed and updated to ensure that the index was reflective of the current economic scenarios with appropriate assumptions included in the models, thus ensuring that varieties excelling in the agronomic traits with the greatest effect on profitability were recognized. The difference between the highest and lowest performing varieties for the grass utilization trait ranged from $€ 23$ to $-€ 24$. A range of $€ 211$ to $€ 43$ was recorded between the highest and lowest ranked varieties within the updated PPI. Spearman's rank correlation between the updated and original PPI lists was 0.96 . The introduction of the utilization subindex will allow farmers to make informed variety selection decisions when reseeding pasture, particularly on their grazing platforms and it will allow a demand-based communication process between the farmer and the grass merchant or breeder, ultimately affecting trait selection for future breeding strategies.

Key words: grazing dairy systems, perennial ryegrass, variety evaluation, economic ranking index

Received January 7, 2021

Accepted May 22, 2021.

*Corresponding author: Michael.ODonovan@teagasc.ie

\section{INTRODUCTION}

The average full-day length of grazing season in Ireland is $235 \mathrm{~d}$ (O'Brien et al., 2018), signifying the importance of grazing within ruminant production systems. Recent changes in European Policy such as the Farm to Fork 2030 program (European Commission, 2020) have restated the desire to move toward production systems with greater sustainability. The sustainability benefits of grassland-based production systems (e.g., economic, product quality, and environmental) are clearly illustrated by Hennessy et al. (2020) and are particularly emphasized in ruminant grazing systems. Incorporating large quantities of grazed pasture into the diet of dairy cows is a key aspect of grass-based ruminant production systems (Horan and Roche, 2020), as this improves farm profitability (Hanrahan et al., 2018) and milk product quality (O'Callaghan et al., 2016) with potential for carbon sequestration (O'Brien et al., 2014b). Perennial ryegrass (Lolium perenne L., perennial ryegrass) is the most important forage species in temperate ruminant systems accounting for up to 95\% of grass seed sales in Ireland (Grogan and Gilliland, 2011). Over time a perennial ryegrass dominant ley will become less productive due to the invasion of weed species. Additionally, the breeding of new, superior perennial ryegrass varieties will surpass the performance of the previously used varieties (McDonagh et al., 2016). Regular reseeding of pasture will maximize the proportion of perennial ryegrass within swards, optimizing farm production and profitability (Shalloo et al., 2011; Tozer et al., 2015).

Perennial ryegrass varieties are independently assessed by state bodies, universities, or breeders in different countries around the world (Gilliland et al., 2020). Within these trials, traits of importance to pasture-based production systems are evaluated. Examples of these traits include herbage production (annual and seasonal), which influences stocking rate; nutritive quality influencing animal production efficiency; persistence; and disease resistance. The relative importance of these traits may differ between regions because cer- 
tain traits may influence production and profitability to a greater or lesser extent than others (Grogan and Gilliland, 2011). Trial data detailing the relative performance of each variety for the measured traits are generally published in the national recommended list of that region (DAFM, 2020).

Perennial ryegrass variety economic selection indices such as the Pasture Profit Index (PPI) in Ireland and the Forage Value Index in New Zealand and Australia have been developed to aid variety selection decisions within the grassland industry. These indices use data from evaluation trials (O'Donovan et al., 2017; Chapman et al., 2017) expressing superior variety performance based on a total merit index (i.e., expressed as an increase in net profit per year). These indices increase the value of the information supplied to the end user, creating a communication tool expressed in a language (i.e., profit) that users more readily relate to. The relative difference between varieties for all traits are expressed in economic terms indicating the additional profit generated by one variety against another (O'Donovan et al., 2017). Farmers can use the PPI to select varieties based on their total economic merit (sum of all traits) or by focusing on individual traits deemed to be of greater importance (McEvoy et al., 2011).

The accuracy of these economic indices may be limited by the agronomic data used to derive the economic merits. Many independent evaluation bodies assess a large number of candidate varieties annually using a cutting management protocol to simulate both frequent rotational grazing (8-10 cuts/yr) and conservation (silage) management systems (Gilliland et al., 2020). Although such mechanical harvests differ from actual varietal use (grazing), cutting systems are deemed the most practical and affordable methodology of evaluation (Wilkins and Humphreys, 2003). Cashman et al. (2016) reported that herbage yield assessed under mechanical harvesting and animal grazing did not differ, indicating that cutting systems were reliable in their assessment. However, within the animal grazed assessment, varieties were grazed to differing postgrazing sward heights, indicating that variation in the quantity of DM removed was observed between varieties (Cashman et al., 2016). Animal grazing variety evaluation conducted by Wims et al. (2013) and Byrne et al. (2018) also reported grazing efficiency differences between perennial ryegrass varieties.

Grazing efficiency of perennial ryegrass varieties influences the amount of herbage that can be utilized (Byrne et al., 2017). Swards that are consistently grazed to low postgrazing sward heights $(<4 \mathrm{~cm})$ support the highest utilization levels (McCarthy et al., 2013). They also negate the requirement for correction by mechani- cal means (topping), which is a huge advantage at farm level where labor availability is becoming increasingly limited (Kelly et al., 2017; Horan and Roche, 2020). Hanrahan et al. (2018) reported that utilization was one of the single largest (controllable) variables affecting profitability of ruminant systems with each additional tonne of DM utilized, increasing profitability of dairy farms by $€ 173 /$ ha. Utilization is a function of herbage production and harvesting by the animal, which can be influenced by perennial ryegrass varieties. Herbage production is already captured in the PPI, but relative differences between varieties for grazing efficiency are not included as yet. Byrne et al. (2018) reported a $0.3 \mathrm{~cm}$ difference between diploids and tetraploids in achieved postgrazing sward height with the increased digestibility and lower tiller density of these varieties, compared with diploids, responsible for the grazing difference. Varietal grazing efficiency evaluation protocols have been developed by Tubritt et al. (2020a), which, in agreement with Byrne et al. (2018), have found important differences between varieties in their ability to be grazed by cattle. The results from these protocols have provided the data necessary to develop a grazing efficiency subindex within the PPI.

The objective of this study was to develop and incorporate a new grazing efficiency subindex into the PPI and to also update the economic assumptions within the index in line with the most recent costs and prices. This index would provide a relative comparison between varieties for their ability to perform within Irish dairy systems. The development of the utilization subindex would require the application of an economic value to the physical trait to generate an economic merit value for the trait.

\section{MATERIALS AND METHODS}

\section{Update of Economic Values}

The Moorepark Dairy Systems Model (MDSM; Shalloo et al., 2004), a stochastic budgetary simulation model, was used to simulate a model farm using the biological data of each variety. The model integrates biological (e.g., milk production, pasture production), physical (e.g., land), and economic processes occurring on dairy farms into a statistical model. Land area is treated as an opportunity cost, with additional land rented when required and leased out when not required for on-farm feeding of animals. Variable costs (fertilizer, contractor charges, veterinary fees, artificial insemination, and feed costs) and fixed costs (machinery running and maintenance, farm maintenance, car, telephone, electricity, and insurance) are based on current prices (updated at regular intervals). The feeds 
offered (pasture, pasture silage, and concentrate) are determined by the MDSM meeting the net energy requirement for milk production and body weight change (Jarrige, 1989). Detailed descriptions of the model are reported in (Shalloo et al., 2004; McEvoy et al., 2011).

Economic values were derived by simulating a physical change in each trait of interest independently (McEvoy et al., 2011). The difference in net profit per hectare before and after the change was simulated, was divided by the change in the trait of interest. This value is the economic value for a one unit change in that trait. The economic value of a trait can be expressed in the equation:

Economic value $=\Delta$ net margin per hectare $/$

$\Delta$ in trait of interest (McEvoy et al., 2011).

Based on projected input and output prices, economic values were updated. The update of these input values reflects the price changes that are faced by the industry. Table 1 displays the updated price assumptions used within the MDSM to determine the economic value of each subindex. In particular the economic values that were updated included fertilizer price (calcium ammonium nitrate and urea were reduced by $€ 20 / \mathrm{t}$ ), milk price [increased to $29.5 \mathrm{c} / \mathrm{L}$ (euro cents/liter)], the flat VAT (value-added tax) rate increased to $5.4 \%$, whereas a full review was completed for reseeding cost. Up-to-date information on all factors contributing to a complete reseeding of pasture were sought from various sources such as Teagasc (2014) and the Farm Contractors of Ireland (FCI, 2019). Table 2 displays the updated reseeding costs for 2020. Overall the average costs associated with reseeding have increased from $€ 742$ to $€ 799$ (average of plow and minimum tillage cultivation) with increased cost of farm operations (spraying and cultivation) primarily responsible.

Table 1. Parameter values within the Moorepark Dairy Systems Model updated to reflect current market prices in 2020

\begin{tabular}{lcc}
\hline Variable & $\begin{array}{c}\text { Original } \\
\text { value }\end{array}$ & $\begin{array}{c}\text { Updated } \\
\text { value }\end{array}$ \\
\hline Farm size $($ ha) & 40 & 40 \\
Gross milk value $(€ / \mathrm{L})$ & 0.270 & 0.295 \\
Fat value $(€ / \mathrm{kg})$ & 3.13 & 3.60 \\
Protein value $(€ / \mathrm{kg})$ & 6.27 & 7.21 \\
Price ratio of protein:fat & $2: 1$ & $2: 1$ \\
Opportunity cost of land $(€ / \mathrm{ha})$ & 297 & 297 \\
Concentrate cost $(€ / \mathrm{t})$ & 220 & 250 \\
Calcium ammonium nitrate $(€ / \mathrm{t})$ & 360 & 280 \\
Urea $(€ / \mathrm{t})$ & 420 & 360 \\
N:P:K fertilizer, 0:7:30 $(€ / \mathrm{t})$ & 340 & 420 \\
First-cut grass silage $(€ /$ ha) & 284 & 309 \\
Second-cut grass silage $(€ /$ ha) & 235 & 235 \\
\hline
\end{tabular}

Table 2. The increase in reseeding costs (€/ha) from 2014 to 2020 in Ireland ${ }^{1}$

\begin{tabular}{lcc}
\hline Item & 2014 & 2020 \\
\hline Glyphosate & 20 & 20 \\
Spraying & 25 & 37.5 \\
Plow (minimum tillage) & $75(60)$ & $112.5(75)$ \\
Leveling & 35 & 37.5 \\
Lime and spreading & 60 & 60 \\
Fertilizer & 134 & 112.5 \\
Fertilizer spreading & 25 & 25 \\
Seed & 173 & 175 \\
Sowing & 100 & 125 \\
Rolling & 25 & 25 \\
Postemergence spray & 45 & 50 \\
Spraying & 25 & 37.5 \\
Total (minimum tillage) & $742(727)$ & $818(780)$ \\
\hline
\end{tabular}

${ }^{1}$ Costs estimated from FCI (2019).

\section{Variety Grazing Efficiency Data}

Varietal grazing efficiency evaluation protocols were established by Tubritt et al. (2020a). This trial determined the grazing efficiency performance of each variety. All varieties $(\mathrm{n}=30)$, selected from the 2016 Irish Department of Agriculture, Food and the Marine (DAFM) Recommended List (DAFM, 2016) were sown in an experimental plot grazing trial. Plots measured $8 \times 4.5 \mathrm{~m}\left(36 \mathrm{~m}^{2}\right)$ and were sown in a randomized block design in 3 replicates. These plots were rotationally grazed by dairy cattle when average herbage cover across all plots was estimated to be $1,400 \mathrm{~kg}$ of DM/ha (above cutting height), which typically led to grazing intervals of $21 \mathrm{~d}$ in mid season (longer in spring and autumn). Three years of evaluation were conducted, which culminated in 27 individual grazing rotations. Pre- and postgrazing sward heights were measured at each grazing rotation with a Jenquip rising plate meter (Jenquip Rising Plate Pasture Meters; diameter 355 $\mathrm{mm}$ and $3.2 \mathrm{~kg} / \mathrm{m}^{2}$ ). The agronomic results from this study are described in Tubritt et al. (2020b).

\section{Residual Grazed Height}

Residual grazed height (RGH) was developed to accurately compare variety grazing efficiency (Tubritt et al., 2020a). As variety plots were grazed concurrently at an average herbage cover of $1,400 \mathrm{~kg}$ of $\mathrm{DM} / \mathrm{ha}$, a range in pregrazing sward height existed between varieties. This range was influenced by a variety's genetic propensity for growth and by the previous postgrazing sward height of that variety. Postgrazing sward height was recorded from each plot but pregrazing sward height was found to have a significant effect on postgrazing sward height (i.e., varieties with lower pregrazing sward heights, achieved lower postgrazing sward heights). 
Therefore, comparing variety grazing efficiency based solely on postgrazing sward height was biased toward varieties with lower pregrazing sward heights.

The RGH was used to account for the pregrazing differences between varieties and was calculated as achieved postgrazing sward height minus predicted postgrazing sward height. Predicted postgrazing sward height was calculated for each variety based on a regression model using year, grazing rotation, block and pregrazing sward height as factors within the model. A variety with a higher pregrazing sward height was predicted to have higher postgrazing sward height. The actual postgrazing sward height of a variety was compared with the predicted postgrazing sward height of the same variety. A full description of the model and how it was applied is described by Tubritt et al. (2020a). The RGH values can be either positive or negative. Negative RGH values indicate that a variety was consistently grazed to a lower postgrazing sward height than predicted by the regression model therefore negative RGH values are indicative of high grass utilization performance. Positive RGH values indicate that a variety failed to be grazed lower than that predicted by the model and therefore has poor grazing efficiency performance. The RGH value corresponds to the magnitude of the difference between predicted and achieved postgrazing sward height. The greater the RGH value the greater the disparity between predicted and postgrazing sward height.

\section{Development of the Utilization Trait}

The development of the grass utilization subindex involved (1) determining the grass utilization percentage of each variety and (2) calculating and applying the economic value of increased utilization. The economic value of increased utilization is based on the assumption that a $1 \%$ increase in utilization increases the amount of herbage DM grazed by an animal. Likewise, a $1 \%$ decrease in utilization, reduces the amount of herbage DM grazed by an animal. Additional herbage utilized by animals within the MDSM will displace the requirement for grass silage and concentrate on an equal energy basis in the spring and autumn and will increase in the carrying capacity of the farm, allowing a higher stocking rate to be maintained in the main grazing season.

Determining the Utilization Percentage of Each Variety. Within the PPI, base DM production is assumed to be $9,100 \mathrm{~kg}$ of $\mathrm{DM} / \mathrm{ha}$ (O'Donovan et al., 2017). This level was calculated as the average level of DM production on commercial grassland farms in
Ireland (Shalloo, 2009). Within the MDSM, the economic value of each seasonal DM yield trait is calculated assuming herbage utilization levels of 90,85 , and $80 \%$ for spring, summer, and autumn (O'Donovan and Kennedy, 2007; McEvoy et al., 2011). The average of these seasonal utilization values (85\%) was assumed as the base annual utilization level. Base utilizable yield was calculated by multiplying base DM production by the assumed base utilization level (e.g., 9,100 kg of $\mathrm{DM} / \mathrm{ha} \times 85 \%=7,735 \mathrm{~kg}$ of $\mathrm{DM} /$ ha). Base variety grazing performance was expressed as an RGH of zero. Combining all these factors, the base variety utilization performance against which all varieties are compared is an RGH of zero equaling a base grass utilization potential of $85 \%$, thereby resulting in a utilizable yield of $7,735 \mathrm{~kg}$ of $\mathrm{DM} /$ ha (i.e., $\mathrm{RGH}=0=85 \%$ utilization $=$ $7,735 \mathrm{~kg}$ of DM/ha).

The grass utilization percentage of each variety was calculated by multiplying each respective varietal RGH value by herbage density to determine the additional or reduced DM utilized by each variety relative to the control at each grazing. A common herbage density was assumed at $250 \mathrm{~kg}$ of $\mathrm{DM} / \mathrm{ha}$ per $\mathrm{cm}$, as this value is commonly used in grassland research and grassland management calculations (Curran et al., 2010; McSweeney et al., 2019; Teagasc, 2021). The additional/ reduced DM was then multiplied by 8 assumed grazing rotations that take place during the production year (Maher et al., 2021), resulting in the annual additional or reduced DM of each variety. Summing the annual additional or reduced DM to the base utilizable yield $(7,735 \mathrm{~kg}$ of $\mathrm{DM} / \mathrm{ha})$ determined the total utilizable yield of each variety across the year. This was expressed relative to total base DM production $(9,100 \mathrm{~kg}$ of DM/ ha) to determine the grass utilization percentage of the varieties.

Calculating the Utilization Economic Values. The additional/reduced DM created from a $1 \%$ change in utilization was determined (equal to $1 \%$ of total yield). This value was multiplied by an economic value of $€ 0.04 / \mathrm{kg}$ of DM to determine the economic value of a $1 \%$ change in utilization. The economic value of $€ 0.04$ was chosen to match the mid-season DM economic value as the greatest variation in utilization occurs at this point of the grazing season and over half (5 out of 8) grazing events are assumed in mid-season. The utilization economic value of each variety was calculated as follows:

$$
\begin{aligned}
& \text { Variety utilization } \% \text { - base utilization } \% \\
& \times \text { economic value of utilization. }
\end{aligned}
$$




\section{Relative Emphasis}

The importance of each subindex within the PPI and how the updated economic values and addition of the new trait affected this was calculated using the relative emphasis method as described in O'Donovan et al. (2017). Determining the relative emphasis of all traits provides a greater understanding of the importance of each trait; which is only partially indicated by the economic value alone. Trait heritability estimates are used to determine the level of variation caused by genetic variation between varieties, which is used to determine the relative emphasis of each trait. Heritability estimates for the existing DM production (including silage) and nutritive quality traits were derived from Conaghan and Casler (2011) with values of 0.50 and 0.42 for DM yield and in vitro digestibility, respectively. No indication of heritability of grazing efficiency or persistence could be determined so heritability (repeatability) of grazing efficiency was calculated from the existing grazing efficiency data generated by Tubritt et al. (2020a) and from the recommended list data for persistence. The variance components for variety, year, and residual were calculated using a linear mixed model and used to calculate the heritability according to:

$$
\begin{gathered}
\left(\mathrm{V} \sigma^{2}\right) /\left[\mathrm{V} \sigma^{2}+\left(\mathrm{Y} \sigma^{2} / \mathrm{Yn}\right)+\left(\mathrm{R} \sigma^{2} / \mathrm{Rn}\right)\right. \\
\left.+\left(\text { Residual } \sigma^{2} / \mathrm{Yn} \times \mathrm{Rn}\right)\right],
\end{gathered}
$$

where $\mathrm{V}^{2}$ is the varietal variance, $\mathrm{Y}^{2}$ is the variance between years, and $\mathrm{R} \sigma^{2}$ is the variance between replicates; $\mathrm{Yn}$ is the number of years and $\mathrm{Rn}$ is the number of replicates.

Genetic standard variation for each trait was calculated as the phenotypic variation observed between the varieties evaluated, multiplied by the estimated trait genetic heritability. The relative contribution of a trait was calculated as the product of the genetic standard deviation between varieties, multiplied by the economic value of that trait, divided by the sum of this calculation for all traits in the index (VanRaden, 2002):

$$
\text { Emphasis }=[(a i \times \sigma i) / \operatorname{Sum}(a j \times \sigma j)] \times 100,
$$

where ai and aj are the economic value for traits $i$ and $\mathrm{j}$, respectively, and $\sigma \mathrm{i}$ and $\sigma \mathrm{j}$ are the genetic standard deviations for traits $\mathrm{i}$ and $\mathrm{j}$, respectively.

\section{Rank Correlation}

Spearman's rank correlation was calculated between the original 2016 PPI and the updated PPI list to determine the effect of revising the economic values and incorporating the new utilization subindex. The PROC CORR procedure was used within the statistical program SAS 9.4 (SAS Institute Inc.) to analyze the data.

\section{RESULTS}

The agronomic data used in the analysis was derived from the 2016 Irish Recommended list published by DAFM (2016). This data set contains the agronomic data of all varieties assessed over a minimum of 2 separate sowing years. The effect of updating the economic values of each subindex was calculated by applying the new economic values to the original agronomic data (DAFM, 2016).

\section{Herbage DM Production Subindices}

In the 2016 PPI list (DAFM, 2016), spring herbage $\mathrm{DM}$ production ranged from 0.92 to $1.56 \mathrm{t}$ of $\mathrm{DM} / \mathrm{ha}$ which equated to a -€13 to €92 range in the spring DM production subindex. Summer DM production ranged from 6.58 to $7.45 \mathrm{t}$ of $\mathrm{DM} /$ ha, resulting in a range of $€ 18$ to $€ 51$ between the lowest and highest performing varieties. Autumn DM yield ranged from 1.98 to $2.49 \mathrm{t}$ of $\mathrm{DM} /$ ha equating to a $€ 56$ difference between varieties in the original PPI list ( $€ 7-€ 63)$.

Updating the economic assumptions of MDSM resulted in the economic value of spring DM production increasing from $€ 0.163$ to $€ 0.165 / \mathrm{kg}$ of DM/ha (Table 3 ). When the new economic value was applied, the difference between the highest and lowest varieties for spring DM ranged from -€13 to €93. The economic value of summer DM production remained unchanged $(€ 0.038 / \mathrm{kg}$ of $\mathrm{DM} / \mathrm{ha})$, therefore there was no change in the summer DM economic value of varieties. The updated autumn DM economic value increased from $€ 0.103$ to $€ 0.111 / \mathrm{kg}$ of $\mathrm{DM} / \mathrm{ha}$. Applying the new economic value resulted in the lowest and highest performing varieties ranging from $€ 7$ to $€ 64$.

\section{Quality Subindex}

Seasonal DM digestibility (DMD) decreased from April to July. April DMD ranged from 841.3 to 869.7 $\mathrm{g} / \mathrm{kg}$ of DM; May DMD ranged from 842.2 to $875.9 \mathrm{~g} /$ $\mathrm{kg}$ of DM; June DMD ranged from 809.3 to $856.9 \mathrm{~g} / \mathrm{kg}$ of DM; and July DMD ranged from 801.9 to $834.5 \mathrm{~g} /$ $\mathrm{kg}$ of DM (DAFM, 2016). The economic value of April, May, June, and July DMD was €0.01, €0.07, €0.09, and $€ 0.05$ within the 2016 PPI list (Table 3 ). The variation between varieties for nutritive quality in the 2016 PPI list ranged from $-€ 39$ to $€ 65$.

The economic value of each monthly nutritive quality subindex increased in value when the updated 
Table 3. Updated economic values and relative emphasis of Pasture Profit Index traits

\begin{tabular}{|c|c|c|c|c|}
\hline \multirow[b]{2}{*}{ Subindex $^{1}$} & \multicolumn{2}{|c|}{ Economic value $(€)$} & \multicolumn{2}{|c|}{ Relative emphasis } \\
\hline & 2016 & 2020 & 2016 & 2020 \\
\hline Spring DM (kg of DM/ha) & 0.163 & 0.165 & 0.12 & 0.18 \\
\hline Summer DM (kg of DM/ha) & 0.038 & 0.038 & 0.09 & 0.05 \\
\hline Autumn DM (kg of DM/ha) & 0.103 & 0.0111 & 0.06 & 0.08 \\
\hline April DMD ( $\mathrm{g} / \mathrm{kg}$ of $\mathrm{DM})$ & 0.001 & 0.001 & 0.01 & 0.01 \\
\hline May DMD (g/kg of DM) & 0.007 & 0.009 & 0.05 & 0.05 \\
\hline June DMD (g/kg of DM) & 0.009 & 0.011 & 0.08 & 0.08 \\
\hline July DMD (g/kg of DM) & 0.005 & 0.010 & 0.05 & 0.08 \\
\hline Silage 1 st cut (kg of DM/ha) & 0.043 & 0.040 & 0.11 & 0.08 \\
\hline Silage 2 nd cut ( $\mathrm{kg}$ of $\mathrm{DM} / \mathrm{ha}$ ) & 0.030 & 0.028 & 0.08 & 0.05 \\
\hline Persistency (times/year) & 56 & 67 & 0.35 & 0.30 \\
\hline Grazing utilization (\%) & - & 3.64 & - & 0.05 \\
\hline
\end{tabular}

${ }^{1} \mathrm{DMD}=\mathrm{DM}$ digestibility.

economic assumptions were used. The updated DMD economic values for April, May, June, and July were $€ 0.01, € 0.09$, €0.11, and €0.10, respectively. Applying these updated economic values increased the disparity between the highest and lowest performing variety within the quality subindex. The economic value of the lowest performing variety for quality was - 443 (variety 8 ), whereas the highest performing variety had a value of $€ 72$ (variety 2).

\section{Silage Subindex}

First-cut silage yields ranged from 4.08 to $5.21 \mathrm{t}$ of $\mathrm{DM} /$ ha. Second-cut silage yields ranged from 3.47 to $4.56 \mathrm{t}$ of $\mathrm{DM} /$ ha. The economic value of first and second-cut silage in the original PPI list was €0.043 and $€ 0.030 / \mathrm{kg}$ of DM per ha. The range between the highest and lowest ranking varieties within the silage index was $-€ 5$ to $€ 39$.

Updating the economic assumptions used in the MDSM caused the economic value of both first and second-cut silage to fall to $€ 0.040$ and $€ 0.028$, respectively. When the updated economic values were applied, the disparity between the highest and lowest performing varieties for the silage subindex decreased to $€ 43$. The new economic value of highest performing variety decreased by $€ 1$ to $€ 38$, whereas the lowest performing variety remained at $-€ 5$.

\section{Persistency Subindex}

The majority of varieties within the 2016 PPI list were predicted to maintain persistency up to $12 \mathrm{yr}$, which equates to an economic value of zero. The remaining varieties had persistency value of $-€ 5$, with one additional variety having a value of $-€ 11$.

The economic cost of reseeding increased, which increased the economic value of persistency. The original persistency value was $€ 56 / \mathrm{yr}$, and this value rose to $€ 67$ when the updated cost of reseeding was applied. When the updated persistency economic value was applied, varieties whose persistency economic value was $-€ 5$, fell further to $-€ 6$. The persistency value of the remaining variety fell to $-€ 14$.

\section{Grass Utilization Subindex}

The utilization percentage of each variety (and how it is calculated) is presented in Table 4. Annual RGH ranged from -0.30 to $0.29 \mathrm{~cm}$, which resulted in a difference of $1,175 \mathrm{~kg}$ of $\mathrm{DM} / \mathrm{ha}$ per year [147 kg of $\mathrm{DM} /$ ha at each grazing rotation $(\mathrm{n}=8)]$ in additional utilized herbage between the most and least utilizable varieties ( -583 to $592 \mathrm{~kg}$ of $\mathrm{DM} / \mathrm{ha}$ per year). The additional or reduced herbage DM of each variety was then summed to $7,735 \mathrm{~kg}$ of $\mathrm{DM} /$ ha per year (base utilizable yield) and expressed out of $9,100 \mathrm{~kg}$ of DM/ ha per year (base total yield) to determine the utilization potential of each variety.

Simulating a $1 \%$ increase in utilization resulted in an additional $91 \mathrm{~kg}$ of $\mathrm{DM} / \mathrm{ha}$ per year of grass utilized (11 kg per grazing rotation). The resultant increase in farm profit was $€ 3.64$ (91 $\mathrm{kg}$ of $\mathrm{DM} /$ ha per year $\times$ $€ 0.04)$. Table 4 shows the application of the utilization economic value to each variety. Utilization ranged from $79 \%$ (variety 10) to $92 \%$ (variety 7 ), a difference of $13 \%$ which created a range in the utilization subindex of $-€ 23$ to $€ 24$.

\section{Updated PPI List}

Table 5 displays the updated PPI list with the addition of the utilization subindex and the application of the updated economic values for each subindex applied. The range between the highest and lowest variety for overall PPI was $€ 168$, an increase of $€ 22$. The over- 
all PPI of the highest ranked variety increased by $€ 1$. The largest increase in overall PPI was €31, whereas the largest decrease was $€ 23$. These changes caused re-ranking between varieties with the largest fall in ranking occurring for variety 23 with a fall of 4 places. The largest increase in ranking occurred for variety 28 with an increase of 6 places. Despite these changes, re-ranking of varieties within the index was minimal with a Spearman's rank correlation of 0.96 recorded between the original variety ranking and the updated ranking (with the addition of the utilization subindex and the application of the updated economic values; Table 6). Additionally, a rank correlation of 0.54 was found between the 2016 quality subindex and the utilization subindex.

\section{Relative Emphasis}

The heritability estimates of grazing efficiency and persistence were 0.21 and 0.27 , respectively. Updating the economic values of the existing traits and incor- porating the utilization subindex changed the relative emphasis of the subindices. Table 3 displays the change in emphasis between the 2016 PPI list and the updated index. The relative emphasis of spring and autumn DM production increased to 18 and $8 \%$, respectively, whereas the emphasis on summer DM production decreased to $5 \%$. The overall emphasis of the quality subindex increased to $22 \%$ ( $+4 \%$ ). Relative contributions of firstand second-cut silage decreased to 8 and $5 \%$, respectively. Persistence relative emphasis was calculated at $30 \%$. The relative emphasis of the utilization trait was calculated as $5 \%$.

\section{DISCUSSION}

Since its introduction, the PPI has received widespread industry acceptance. This acceptance is evident in the increased sales of high-ranking varieties compared with lower-ranking varieties within the PPI list (unpublished data, David Cummins, Department of Agriculture, Food and the Marine, Ireland). The key

Table 4. Annual utilization values for varieties determined from varietal residual grazed height $(\mathrm{RGH})^{1 \mathrm{a}}$

\begin{tabular}{|c|c|c|c|c|c|c|}
\hline Variety & $\begin{array}{l}\text { Annual } \\
\text { RGH } \\
(\mathrm{cm})\end{array}$ & $\begin{array}{l}\text { Difference in herbage } \\
\text { yield per grazing } \\
\text { (kg of DM/ha) }\end{array}$ & $\begin{array}{l}\text { Annual difference } \\
\text { in utilized herbage } \\
\text { (kg of DM/ha) }\end{array}$ & $\begin{array}{c}\text { Annual utilizable } \\
\text { herbage yield } \\
\text { (kg of DM/ha) }\end{array}$ & $\begin{array}{c}\text { Utilization }^{2} \\
(\%)\end{array}$ & $\begin{array}{l}\text { Utilization } \\
\text { economic } \\
\text { value }^{3}(€)\end{array}$ \\
\hline Variety 7 & -0.30 & 74 & 592 & 8,327 & 92 & 24 \\
\hline Variety 28 & -0.27 & 67 & 535 & 8,270 & 91 & 21 \\
\hline Variety 30 & -0.21 & 52 & 418 & 8,153 & 90 & 17 \\
\hline Variety 9 & -0.18 & 46 & 370 & 8,105 & 89 & 15 \\
\hline Variety 6 & -0.18 & 46 & 367 & 8,102 & 89 & 15 \\
\hline Variety 17 & -0.18 & 46 & 365 & 8,100 & 89 & 15 \\
\hline Variety 11 & -0.15 & 38 & 306 & 8,041 & 88 & 12 \\
\hline Variety 20 & -0.13 & 34 & 268 & 8,003 & 88 & 11 \\
\hline Variety 5 & -0.11 & 28 & 227 & 7,962 & 87 & 9 \\
\hline Variety 24 & -0.09 & 23 & 187 & 7,922 & 87 & 7 \\
\hline Variety 18 & -0.06 & 15 & 122 & 7,857 & 86 & 5 \\
\hline Variety 13 & -0.05 & 12 & 99 & 7,834 & 86 & 4 \\
\hline Variety 29 & -0.05 & 12 & 97 & 7,832 & 86 & 4 \\
\hline Variety 27 & -0.01 & 4 & 29 & 7,764 & 85 & 1 \\
\hline Variety X & 0.00 & 0 & 0 & 7,735 & 85 & 0 \\
\hline Variety 2 & 0.01 & -2 & -14 & 7,721 & 85 & -1 \\
\hline Variety 4 & 0.03 & -8 & -63 & 7,672 & 84 & -3 \\
\hline Variety 3 & 0.05 & -13 & -100 & 7,635 & 84 & -4 \\
\hline Variety 25 & 0.05 & -13 & -107 & 7,628 & 84 & -4 \\
\hline Variety 14 & 0.07 & -16 & -132 & 7,603 & 84 & -5 \\
\hline Variety 1 & 0.08 & -20 & -163 & 7,572 & 83 & -7 \\
\hline Variety 21 & 0.08 & -20 & -164 & 7,571 & 83 & -7 \\
\hline Variety 23 & 0.11 & -29 & -228 & 7,507 & 82 & -9 \\
\hline Variety 19 & 0.14 & -36 & -286 & 7,449 & 82 & -11 \\
\hline Variety 16 & 0.15 & -38 & -302 & 7,433 & 82 & -12 \\
\hline Variety 15 & 0.16 & -40 & -323 & 7,412 & 81 & -13 \\
\hline Variety 26 & 0.17 & -42 & -333 & 7,402 & 81 & -13 \\
\hline Variety 12 & 0.18 & -44 & -351 & 7,384 & 81 & -14 \\
\hline Variety 22 & 0.20 & -51 & -406 & 7,329 & 81 & -16 \\
\hline Variety 8 & 0.21 & -53 & -427 & 7,308 & 80 & -17 \\
\hline Variety 10 & 0.29 & -73 & -583 & 7,152 & 79 & -23 \\
\hline
\end{tabular}

${ }^{1}$ RGH data from Tubritt et al. (2020b).

${ }^{2}$ Utilization $=$ annual utilizable herbage yield $/ 9,100 \mathrm{~kg}$ of DM per hectare (base total yield).

${ }^{3}$ Utilization economic value $=$ utilization $\%-85 \%$ (base utilization $\%$ ) $\times € 3.64$. 
aim of the PPI is to identify perennial ryegrass varieties that create the greatest economic return. Traits of importance within the PPI must contribute to the low-cost competitive advantage of grass-based systems. The contribution of grass utilization to grass-based ruminant production systems has been outlined by Dillon et al. (2008), Ramsbottom et al. (2015), and Hanrahan et al. (2018). Differences in the ability of animals to utilize different perennial ryegrass varieties have been recognized in Byrne et al. (2018) and Tubritt et al. (2020a). Therefore, there was a requirement to include a grass utilization trait within the perennial ryegrass selection index.

Limited evaluation of perennial ryegrass varieties within grazing systems has taken place as the development and operation of such protocols are costly. The evaluation developed by Tubritt et al. (2020a) provides an affordable methodology to assess grazing suitability. A base value of $0 \mathrm{~cm} \mathrm{RGH}$ was assumed to compare grazing efficiency between perennial ryegrass varieties. Values below 0 RGH are consistently grazed lower than the control variety and so support greater grass utilization. Interpreting RGH values can be confusing for farmers given that negative values are associated with superior or desirable grazing efficiency which can be nonintuitive. Expressing RGH as an economic value removes this complexity with industry understanding and acceptance of economic values within the PPI well established (Gilliland et al., 2018; O'Donovan et al., 2018). Aligning the target grass utilization performance to the mean grazing efficiency of all varieties allowed for a relative comparison to be made. This target utilization value ( $85 \%$ ) has been developed from grassland management studies aimed to maximize the quantity and quality of grass provided to cows (O'Donovan and Kennedy, 2007; Macdonald et al., 2008; Ganche et al., 2013).

Incorporating grazing efficiency evaluations into the existing recommended list protocols is required to provide an indication of a variety's utilization potential before becoming recommended. Currently varieties must be evaluated for 2 individual sowing years to become recommended (DAFM, 2020). An indication of variety herbage production and nutritive quality potential will be available after one year of evaluation. High-performing candidate varieties identified within

Table 5. Updated Pasture Profit Index (PPI) of perennial ryegrass varieties with new trait economic values applied and the addition of the utilization subindex ${ }^{1}$

\begin{tabular}{|c|c|c|c|c|c|c|c|c|c|c|}
\hline Variety & Ploidy $^{2}$ & $\begin{array}{l}\text { Heading } \\
\text { date }\end{array}$ & Spring & Summer & Autumn & Silage & Quality & Persistency & Utilization & $\begin{array}{l}\text { Updated } \\
\text { PPI total }\end{array}$ \\
\hline Variety 3 & $\mathrm{D}$ & June 05 & 48 & 50 & 64 & 14 & 40 & 0 & -4 & 211 \\
\hline Variety 2 & $\mathrm{~T}$ & June 09 & 38 & 44 & 32 & 25 & 72 & -6 & -1 & 205 \\
\hline Variety 13 & $\mathrm{~T}$ & May 30 & 32 & 42 & 43 & 23 & 43 & -6 & 4 & 182 \\
\hline Variety 4 & $\mathrm{~T}$ & June 09 & 45 & 51 & 38 & 14 & 33 & 0 & -3 & 179 \\
\hline Variety 7 & $\mathrm{~T}$ & June 02 & 7 & 37 & 31 & 11 & 68 & 0 & 24 & 178 \\
\hline Variety 1 & $\mathrm{D}$ & May 31 & 23 & 47 & 36 & 8 & 71 & -6 & -7 & 173 \\
\hline Variety 30 & $\mathrm{~T}$ & June 11 & 22 & 39 & 26 & 15 & 51 & 0 & 17 & 170 \\
\hline Variety 24 & $\mathrm{~T}$ & May 28 & 33 & 41 & 29 & 37 & 22 & 0 & 7 & 170 \\
\hline Variety 23 & D & May 24 & 93 & 25 & 33 & 15 & 2 & 0 & -9 & 160 \\
\hline Variety 6 & $\mathrm{~T}$ & June 06 & 25 & 41 & 17 & 9 & 41 & 0 & 15 & 148 \\
\hline Variety 5 & $\mathrm{~T}$ & June 04 & 13 & 38 & 27 & 4 & 56 & 0 & 9 & 148 \\
\hline Variety 18 & $\mathrm{~T}$ & May 22 & 54 & 30 & 26 & 26 & 8 & -6 & 5 & 142 \\
\hline Variety 26 & $\mathrm{D}$ & May 21 & 70 & 29 & 22 & 20 & -25 & 0 & -13 & 103 \\
\hline Variety 16 & $\mathrm{D}$ & June 01 & 34 & 40 & 32 & 7 & 0 & 0 & -12 & 102 \\
\hline Variety 12 & $\mathrm{D}$ & June 07 & 26 & 30 & 24 & -5 & 49 & -14 & -14 & 97 \\
\hline Variety 8 & $\mathrm{D}$ & May 22 & 55 & 29 & 24 & 38 & -43 & 0 & -17 & 86 \\
\hline Variety 19 & $\mathrm{D}$ & June 02 & 39 & 32 & 33 & -1 & -18 & 0 & -11 & 75 \\
\hline Variety 27 & $\mathrm{D}$ & June 02 & 21 & 27 & 16 & 8 & -2 & 0 & 1 & 72 \\
\hline Variety 10 & $\mathrm{D}$ & June 06 & 34 & 42 & 10 & 16 & -11 & 0 & -23 & 68 \\
\hline Variety 29 & $\mathrm{D}$ & June 04 & 40 & 18 & 8 & -1 & 3 & -6 & 4 & 67 \\
\hline Variety 15 & $\mathrm{D}$ & June 02 & 27 & 35 & 20 & 8 & -11 & 0 & -13 & 67 \\
\hline Variety 22 & $\mathrm{D}$ & June 03 & 26 & 31 & 12 & 15 & -25 & 0 & -16 & 43 \\
\hline
\end{tabular}

${ }^{1}$ Trait performance values expressed in $€$.

${ }^{2} \mathrm{D}=$ diploid; $\mathrm{T}=$ triploid. 
Table 6. Change in rank of varieties based on the updated total Pasture Profit Index (PPI) values caused by application of updated economic values and the additional of the utilization subindex (Spearman's rank correlation $=0.96$ )

\begin{tabular}{|c|c|c|c|c|c|}
\hline \multirow[b]{2}{*}{ Variety } & \multicolumn{2}{|c|}{2016 PPI } & \multicolumn{2}{|c|}{ Updated PPI } & \multirow[b]{2}{*}{ Change in rank } \\
\hline & PPI total & Rank & New total & New rank & \\
\hline Variety 3 & 210 & 1 & 211 & 1 & - \\
\hline Variety 2 & 199 & 2 & 205 & 2 & - \\
\hline Variety 21 & 190 & 3 & 183 & 3 & - \\
\hline Variety 13 & 174 & 6 & 182 & 4 & 2 \\
\hline Variety 4 & 177 & 4 & 179 & 5 & -1 \\
\hline Variety 7 & 147 & 11 & 178 & 6 & 5 \\
\hline Variety 25 & 175 & 5 & 175 & 7 & -2 \\
\hline Variety 17 & 156 & 10 & 175 & 8 & 2 \\
\hline Variety 1 & 173 & 7 & 173 & 9 & -2 \\
\hline Variety 24 & 160 & 9 & 170 & 10 & -1 \\
\hline Variety 30 & 147 & 12 & 170 & 11 & 1 \\
\hline Variety 23 & 168 & 8 & 160 & 12 & -4 \\
\hline Variety 5 & 133 & 14 & 148 & 13 & 1 \\
\hline Variety 6 & 129 & 15 & 148 & 14 & 1 \\
\hline Variety 18 & 137 & 13 & 142 & 15 & -2 \\
\hline Variety 9 & 125 & 16 & 139 & 16 & - \\
\hline Variety 20 & 124 & 17 & 138 & 17 & - \\
\hline Variety 11 & 112 & 20 & 114 & 18 & 2 \\
\hline Variety 28 & 89 & 25 & 114 & 19 & 6 \\
\hline Variety 14 & 109 & 21 & 104 & 20 & 1 \\
\hline Variety 26 & 118 & 18 & 103 & 21 & -3 \\
\hline Variety 16 & 113 & 19 & 102 & 22 & -3 \\
\hline Variety 12 & 108 & 22 & 97 & 23 & -1 \\
\hline Variety 8 & 107 & 23 & 86 & 24 & -1 \\
\hline Variety 19 & 87 & 26 & 75 & 25 & 1 \\
\hline Variety 27 & 70 & 28 & 72 & 26 & 2 \\
\hline Variety 10 & 91 & 24 & 68 & 27 & -3 \\
\hline Variety 15 & 80 & 27 & 67 & 28 & -1 \\
\hline Variety 29 & 63 & 29 & 67 & 29 & - \\
\hline Variety 22 & 61 & 30 & 43 & 30 & - \\
\hline
\end{tabular}

their first year could be selected and evaluated under animal grazing for 2 seasons, so that a variety's utilization performance is known at recommendation without slowing down the evaluation process. Minimal re-ranking of varieties between years has been recorded for grazing efficiency so assessment under one sowing year (2 evaluation years) may be sufficient (Tubritt et al., 2020a). Additional sowings of varieties will be possible upon recommendation also. Herbage yield of varieties tends to be greater affected by yearly variation due to differing weather events between years (Conaghan et al., 2008). The effect of weather on grazing efficiency is likely to be of a lesser magnitude than DM yield, as weather affects the rate of growth of plants to a greater extent than the expression of plant traits that influence grazing efficiency (Mitchell, 1956). The utilization subindex shows good agreement with varieties evaluated on-farm for postgrazing sward height (Byrne et al., 2017), further supporting the repeatability of the subindex. The regression model developed in Tubritt et al. (2020a) could be used as the standard against which all varieties are assessed. A candidate variety's pregrazing sward height would be inputted into the model and its predicted postgrazing sward height compared with its achieved postgrazing sward height. Alternatively control varieties could be selected from the current study and included within each new sowing of the animal grazing assessment to provide a relative comparison between varieties.

The increased grass utilization supported by the varieties identified in this study may help to reduce costs and to increase productivity (McCarthy et al., 2016). Management strategies such as restricting access time to pasture in periods of adverse weather or ground conditions (on and off grazing) have been developed to increase grazed grass intake during these periods (Kennedy et al., 2009). Use of varieties that have higher grass utilization may further enhance this grazing strategy, promoting increased herbage intake within the restricted access time. Byrne et al. (2018) identified perennial ryegrass plant traits with high correlations to improved grazing efficiency. Many of these traits are also correlated with improved voluntary feed intake, potentially increasing individual animal DM intake at pasture (Jung and Allen, 1995; Taweel, 2007). The incorporation of the utilization subindex into the PPI has the capacity to increase product output from a low-cost feedstuff, increasing the profitability of grass- 
based ruminant production enterprises (O'Donovan et al., 2018).

Poor sward grazing efficiency can be a clear source of dissatisfaction for farmers and is easily recognizable where animals display a reluctance to graze into the lower sward horizons (Kennedy et al., 2009). Such swards are typically grazed to high postgrazing sward heights, which if left uncorrected will increase in stem proportion, reducing sward digestibility in the next grazing rotation(s) (Tuñon et al., 2014). Under such situations, farmers must decide whether to return the animals to graze the remaining DM, or to mechanically cut (top) the remaining DM. Both methods will prevent the development of stem but this increases costs of production and potentially reduces productivity. Mowing ungrazed herbage represents increased labor and machinery costs incurrence. Additionally, mown grass is unutilized feed and is a loss to the system, leading to further cost increases (O'Donovan, 2016). Returning cows to the paddock may require moving them to new pasture outside of regular milking times, thereby increasing labor requirement. Additionally, because European dairy quotas were abolished, increasing herd size has increased the requirement for additional labor on-farm (Deming et al., 2018), leading to increased delegation of labor and a desire to implement simple management systems (Eastwood et al., 2015; Horan and Roche, 2020). Farmer confidence in the ability of swards to be grazed-out fully will allow them to develop weekly grazing plans to be followed by all staff, easing grassland management and reducing farm labor requirements. Sowing varieties excelling in the utilization subindex should ensure that where grassland allocation is correct, target postgrazing sward heights are achieved. Although labor and machinery costs savings are not directly captured in the updated index, varieties with improved grass efficiency are identified and rewarded with improved overall PPI values.

Economic selection indices must be reactive to changes in input and output prices and addition of new traits to ensure that the indices remain relevant. Failure to do so may lead to an over- or underestimation of a variety's ability to perform economically within specialized production systems. The major price changes incorporated into the updated PPI include an increase in milk price (output) and a decrease in fertilizer price (input). Reseeding costs have increased, primarily driven by an increase in the cost of machinery operations. Such high costs of reseeding may act as deterrent against reseeding but many studies show that the return on investment of pasture reseeding is high (Shalloo et al., 2011). Swards with poor herbage production are costing dairy farmers up to €300/ha in lost grass production dur- ing the growing season, therefore reseeding will often repay for itself after 3 years of establishment, (Creighton, 2012; Teagasc, 2017). As reseeding costs increase, there is a rise in the importance of the value of the persistence subindex. The persistence trait is generated based on ground cover change over time, which has been attributed to changes in herbage production over time (Creighton et al., 2012). Within the recommended list, the minimal ground cover change of varieties is such that it is assumed that most varieties do not have to be reseeded within a 12-yr window, with any variety persistent beyond $12 \mathrm{yr}$ assumed to have no persistence costs (O'Donovan et al., 2017).

Agriculture is estimated to contribute to approximately $34 \%$ of Ireland's greenhouse gas emissions (Duffy et al., 2020). Reducing nitrogen loss and greenhouse gas production are some of the efforts being employed to improve the environmental efficiency of animal agriculture (O'Brien et al., 2014a). Perennial ryegrass selection indices may have a valuable role to play (Chapman et al., 2015). Methane emissions have been shown to differ between groups of sheep grazing different perennial ryegrass varieties (Jonker et al., 2018). Such differences may provide the basis for an environmental subindex in future years and is now an area of further investigation; however, determining differences between varieties is the first step. The quality subindex may be used to indirectly select varieties that contribute to improved protein:energy balances in the rumen (Nocek and Russell, 1988). This could potentially reduce the excretion of excess nitrogen from ruminants (Wilkins and Humphreys, 2003). Increasing the proportion of grazed grass in the diets of dairy cows has been shown to increase soil carbon sequestration, due to higher recycling of carbon by grazing animals (Knudsen et al., 2019). Therefore, increased selection of varieties excelling in the utilization subindex may also have an environmental benefit. Future iterations of variety selection indices will have to be more environmentally focused, resulting in the development of new traits and increasing the economic value of existing traits and those with proven environmental benefits (Chapman et al., 2015).

In general, tetraploid varieties displayed greater grazing efficiency than diploids within the study by Tubritt et al. (2020a) and therefore are rewarded within the new utilization subindex, with tetraploid varieties (in general) achieving higher, positive economic values. The increased grazing potential of tetraploid varieties has been identified in previous studies. Their larger cell size and greater ratio of cell contents to cell wall proportion (Burns et al., 2012) lends itself to higher levels of digestibility compared with diploids (Wims 
et al., 2017) which correlates to increased grazing efficiency (Byrne et al., 2018). Despite this correlation, digestibility only explained $50 \%$ of the variation in RGH between varieties in Tubritt et al. (2020b) and therefore, although digestibility is already captured in the PPI quality subindex, the additional variation justifies the inclusion of the utilization subindex. The low rank correlation (0.54) between the original PPI quality ranking and utilization ranking of varieties further demonstrates that both traits are independent measures. Tetraploid sward canopy structure has also been identified as a factor influencing their intake. Mitchell (1995) reported that tall, low density swards are more conducive to grazing, as animals achieve greater intake per bite compared with short, dense swards. Greater extended tiller height (displayed by tetraploids) was also allied to greater intake in studies by Gilliland et al. (2002) and Byrne et al. (2018). The assessment of grazing efficiency and its inclusion within the PPI now captures this grazing efficiency advantage.

Herbage DM yield was lower for tetraploid varieties assessed under animal grazing (Tubritt et al., 2020a). Such yield differences did not match the published performance of varieties within the recommended list. The varieties were grazed concurrently within this study with tetraploids grazed to lower postgrazing sward heights, which reduced the regrowth capacity of these varieties relative to laxly grazed diploid varieties (Grant et al., 1981; Lee et al., 2008). On-farm the risk of over-grazing taking place is less of an issue as grazing animals will have less choice to graze alternative varieties more or less severely. The assessment of herbage yield and grazing efficiency conducted in separate evaluation protocols ensures the independence of the measures within the PPI.

The inclusion of the utilization subindex is likely to increase the demand for varieties excelling in the trait. Poor grazing efficiency varieties will have a reduced role on farm but may excel in other systems such as silage production and so should be marketed toward those systems. The PPI informs the grassland industry on selection decisions, which are likely to increase demand for a smaller number of varieties (with a corresponding decrease in demand for inferior varieties). The selection criteria used by perennial ryegrass variety breeders is influenced by the evaluation protocols used to develop variety recommended lists (Stewart and Hayes, 2011). The inclusion of the utilization subindex will incentivize breeders to increase selection on traits with known correlations to increased grazing efficiency, such as increased OM digestibility, increased leaf proportion and reduced sheath height (Byrne et al., 2018; Tubritt et al., 2020b).

\section{CONCLUSIONS}

The overall economic merit of a perennial ryegrass variety is defined by relative performance of that variety for a given number of traits and the contribution of those traits to the profitability of grass-based ruminant production systems. The robustness and accuracy of the PPI is dependent on reliability of the economic assumptions used to derive the economic value of each trait. The updates to the economic values within the PPI outlined in this paper now match current agricultural industry costs. The inclusion of the grass utilization subindex further enhances the ability of the PPI to identify perennial ryegrass varieties ideally suited to grazing systems, and for the first time places the plant animal interaction with the index. The incorporation of the utilization subindex will incentivize breeders to select for improved grazing efficiency, ultimately increasing the caliber of varieties available to grassland farmers.

\section{ACKNOWLEDGMENTS}

The authors acknowledge the statistical assistance of Stephen Byrne, Teagasc Oakpark. The authors acknowledge funding from Dairy Farm Levy Ireland, Science Foundation Ireland, and the Department of Agriculture, Food and the Marine on behalf of the Government of Ireland under the Grant 16/RC/3835 (VistaMilk). The authors have stated no conflicts of interest.

\section{REFERENCES}

Burns, G., T. Gilliland, D. Grogan, and P. O'Kiely. 2012. Comparison of the agronomic effects of maturity and ploidy in perennial ryegrass. Pages 349-351 in Grassland-A European Resource. European Grassland Federation.

Byrne, N., T. J. Gilliland, L. Delaby, D. Cummins, and M. O'Donovan. 2018. Understanding factors associated with the grazing efficiency of perennial ryegrass varieties. Eur. J. Agron. 101:101-108. https: //doi.org/10.1016/j.eja.2018.09.002.

Byrne, N., T. J. Gilliland, N. McHugh, L. Delaby, A. Geoghegan, and M. O'Donovan. 2017. Establishing phenotypic performance of grass varieties on Irish grassland farms. J. Agric. Sci. 155:16331645. https://doi.org/10.1017/S0021859617000740.

Cashman, P. A., M. McEvoy, T. J. Gilliland, and M. O'Donovan. 2016. A comparison between cutting and animal grazing for dry-matter yield, quality and tiller density of perennial ryegrass cultivars. Grass Forage Sci. 71:112-122. https://doi.org/10.1111/gfs.12166.

Chapman, D., G. Edwards, A. Stewart, M. McEvoy, M. O'Donovan, and G. Waghorn. 2015. Valuing forages for genetic selection: What traits should we focus on? Anim. Prod. Sci. 55:869-882. https:// doi.org/10.1071/AN14838

Chapman, D. F., J. R. Bryant, M. E. Olayemi, G. R. Edwards, B. S. Thorrold, W. H. McMillan, G. A. Kerr, G. Judson, T. Cookson, A. Moorhead, and M. Norriss. 2017. An economically based evaluation index for perennial and short-term ryegrasses in New Zealand dairy farm systems. Grass Forage Sci. 72:1-21. https://doi.org/10 $.1111 /$ gfs. 12213 . 
Conaghan, P., and M. Casler. 2011. A theoretical and practical analysis of the optimum breeding system for perennial ryegrass. Ir. J. Agric. Food Res. 50:47-63.

Conaghan, P., M. Casler, D. McGilloway, P. O'Kiely, and L. Dowley. 2008. Genotypex environment interactions for herbage yield of perennial ryegrass sward plots in Ireland. Grass Forage Sci. 63:107-120. https://doi.org/10.1111/j.1365-2494.2007.00618.x.

Creighton, P. 2012. Current sward renewal practices and the potential of Lolium perenne to enhance sward production, quality and persistency on Irish Dairy farms. PhD thesis. School of Agriculture and Food Science, University College Dublin.

Creighton, P., T. Gilliland, L. Delaby, E. Kennedy, T. Boland, and M. O'Donovan. 2012. Effect of Lolium perenne sward density on productivity under simulated and actual cattle grazing. Grass Forage Sci. 67:526-534. https://doi.org/10.1111/j.1365-2494.2012.00872 .x.

Curran, J., L. Delaby, E. Kennedy, J. P. Murphy, T. M. Boland, and M. O'Donovan. 2010. Sward characteristics, grass dry matter intake and milk production performance are affected by pre-grazing herbage mass and pasture allowance. Livest. Sci. 127:144-154. https://doi.org/10.1016/j.livsci.2009.09.004

DAFM (Department of Agriculture, Food and the Marine). 2016. Grass and White Clover Varieties: Irish Recommended List 2016. DAFM. https://agritech.ie/wp-content/uploads/2016/04/ GrassWhiteCloverRecom2016.pdf.

DAFM (Department of Agriculture, Food and the Marine). 2020. Grass and White Clover Varieties: Irish Recommended List 2020. DAFM. Accessed Aug. 15, 2020. https://agritech.ie/wp-content/ uploads/2016/04/GrassWhiteCloverRecom2016.pdf.

Deming, J., D. Gleeson, T. O'Dwyer, J. Kinsella, and B. O'Brien. 2018. Measuring labor input on pasture-based dairy farms using a smartphone. J. Dairy Sci. 101:9527-9543. https://doi.org/10 $.3168 /$ jds.2017-14288

Dillon, P., T. Hennessy, L. Shalloo, F. Thorne, and B. Horan. 2008. Future outlook for the Irish dairy industry: A study of international competitiveness, influence of international trade reform and requirement for change. Int. J. Dairy Technol. 61:16-29. https:// doi.org/10.1111/j.1471-0307.2008.00374.x.

Duffy, P., K. Black, D. Fahey, B. Hyde, A. Kehoe, J. Murphy, B. Quirke, A. M. Ryan, and J. Ponzi. 2020. Ireland National Inventory Report 2020. Environmental Protection Agency. Accessed Aug. 14, 2020. https://www.epa.ie/publications/monitoring--assessment/ climate-change/air-emissions/NIR-2020_Merge_finalv2.pdf.

Eastwood, C., B. Dela Rue, and M. Neal. 2015. Advancing your management through technology: Options from near and far. Pages 108-116 in Proceedings from South Island Dairy Event, Lincoln, New Zealand. Accessed Aug. 15, 2020. https://side .azurewebsites.net/wp-content/uploads/2015/10/2.5-Advancing -your-management-thru-technology.pdf.

European Commission. 2020. Farm to Fork Strategy: For a Fair, Healthy and Environmentally-Friendly Food System. European Commission.

FCI (The Association of Farm \& Forestry Contractors in Ireland). 2019. FCI Contracting Charges Guide 2019. FCI. https:// 9d54bb03-8960-4a76-80d5-3f66cf06cadd.filesusr.com/ugd/162a95 _d1759440755a4cb59afe79139d609de6.pdf.

Ganche, E., L. Delaby, M. O'Donovan, T. M. Boland, and E. Kennedy. 2013. Direct and carryover effect of post-grazing sward height on total lactation dairy cow performance. Animal 7:1390-1400. https: //doi.org/10.1017/S1751731113000451.

Gilliland, T. J., P. Annicchiarico, B. Julier, and M. Ghesquière. 2020. A proposal for enhanced EU herbage VCU and DUS testing procedures. Grass Forage Sci. 75:227-241.https://doi.org/10.1111/gfs .12492 .

Gilliland, T. J., P. D. Barrett, R. L. Mann, R. E. Agnew, and A. M. Fearon. 2002. Canopy morphology and nutritional quality traits as potential grazing value indicators for Lolium perenne varieties. J. Agric. Sci. 139:257-273. https://doi.org/10.1017/ S0021859602002575.
Gilliland, T. J., D. Hennessy, and T. Ball. 2018. Breeding resilient cultivars for European grass based ruminant production systems. Grassl. Sci. Eur. 23:29-42.

Grant, S. A., G. Barthram, and L. Torvell. 1981. Components of regrowth in grazed and cut Lolium perenne swards. Grass Forage Sci. 36:155-168. https://doi.org/10.1111/j.1365-2494.1981.tb01552.x.

Grogan, D., and T. J. Gilliland. 2011. A review of perennial ryegrass variety evaluation in Ireland. Ir. J. Agric. Food Res. 50:65-81.

Hanrahan, L., N. McHugh, T. Hennessy, B. Moran, R. Kearney, M. Wallace, and L. Shalloo. 2018. Factors associated with profitability in pasture-based systems of milk production. J. Dairy Sci. 101:5474-5485. https://doi.org/10.3168/jds.2017-13223.

Hennessy, D., L. Delaby, A. van den Pol-van Dasselaar, and L. Shalloo. 2020. Increasing grazing in dairy cow milk production systems in Europe. Sustainability 12:2443. https://doi.org/10.3390/ su12062443.

Horan, B., and J. R. Roche. 2020. Defining resilience in pasture-based dairy-farm systems in temperate regions. Anim. Prod. Sci. 60:5566. https://doi.org/10.1071/AN18601.

Jarrige, R. 1989. Ruminant Nutrition: Recommended Allowances and Feed Tables. John Libbey \& Co. Ltd.

Jonker, A., G. Molano, E. Sandoval, P. S. Taylor, C. Antwi, S. Olinga, and G. P. Cosgrove. 2018. Methane emissions differ between sheep offered a conventional diploid, a high-sugar diploid or a tetraploid perennial ryegrass cultivar at two allowances at three times of the year. Anim. Prod. Sci. 58:1043-1048. https://doi.org/10.1071/ AN15597.

Jung, H. G., and M. S. Allen. 1995. Characteristics of plant cell walls affecting intake and digestibility of forages by ruminants. J. Anim. Sci. 73:2774-2790. https://doi.org/10.2527/1995.7392774x.

Kelly, P., L. Shalloo, T. O'Dwyer, M. Beecher, B. Horan, P. French, and P. Dillon. 2017. The People in Dairy Project: A Report on the Future People Requirement of Irish Dairy Farming to Support Sustainable and Profitable Dairy Expansion. Teagasc.

Kennedy, E., M. McEvoy, J. P. Murphy, and M. O'Donovan. 2009 Effect of restricted access time to pasture on dairy cow milk production, grazing behavior, and dry matter intake. J. Dairy Sci. 92:168-176. https://doi.org/10.3168/jds.2008-1091.

Knudsen, M. T., T. Dorca-Preda, S. N. Djomo, N. Peña, S. Padel, L. G. Smith, W. Zollitsch, S. Hörtenhuber, and J. E. Hermansen. 2019. The importance of including soil carbon changes, ecotoxicity and biodiversity impacts in environmental life cycle assessments of organic and conventional milk in Western Europe. J. Clean. Prod. 215:433-443. https://doi.org/10.1016/j.jclepro.2018.12.273.

Lee, J. M., D. J. Donaghy, and J. R. Roche. 2008. Effect of defoliation severity on regrowth and nutritive value of perennial ryegrass dominant swards. Agron. J. 100:308-314. https://doi.org/10.2134/ agronj2007.0099.

Macdonald, K. A., J. W. Penno, J. A. S. Lancaster, and J. R. Roche. 2008. Effect of stocking rate on pasture production, milk production, and reproduction of dairy cows in pasture-based systems. J. Dairy Sci. 91:2151-2163. https://doi.org/10.3168/jds.2007-0630.

Maher, J., M. O' Donovan, M. O'Leary, P. Dillon, J. Dunphy, and J. Douglas. 2021. Grass10 Report. Teagasc. https://www.teagasc.ie/ media/website/publications/2021/Grass10-Report-2017-2020.pdf.

McCarthy, B., L. Delaby, K. M. Pierce, J. McCarthy, C. Fleming, A Brennan, and B. Horan. 2016. The multi-year cumulative effects of alternative stocking rate and grazing management practices on pasture productivity and utilization efficiency. J. Dairy Sci. 99:3784-3797. https://doi.org/10.3168/jds.2015-9763.

McCarthy, B., K. M. Pierce, L. Delaby, A. Brennan, C. Fleming, and B. Horan. 2013. The effect of stocking rate and calving date on grass production, utilization and nutritive value of the sward during the grazing season. Grass Forage Sci. 68:364-377. https://doi .org/10.1111/j.1365-2494.2012.00904.x.

McDonagh, J., M. O'Donovan, M. McEvoy, and T. J. Gilliland. 2016. Genetic gain in perennial ryegrass (Lolium perenne) varieties 1973 to 2013. Euphytica 212:187-199. https://doi.org/10.1007/s10681 $-016-1754-7$. 
McEvoy, M., M. O'Donovan, and L. Shalloo. 2011. Development and application of an economic ranking index for perennial ryegrass cultivars. J. Dairy Sci. 94:1627-1639. https://doi.org/10.3168/jds .2010-3322.

McSweeney, D., N. E. Coughlan, R. N. Cuthbert, P. Halton, and S. Ivanov. 2019. Micro-sonic sensor technology enables enhanced grass height measurement by a Rising Plate Meter. Inf. Process. Agric. 6:279-284. https://doi.org/10.1016/j.inpa.2018.08.009.

Mitchell, K. 1956. Growth of pasture species under controlled environment. 1. Growth at various levels of constant temperature. N. Z. J. Sci. Technol. Sect. A 38:203-215.

Mitchell, R. J. 1995. The effects of sward height, bulk density and tiller structure on the ingestive behaviour of red deer and Romney sheep. PhD thesis. Plant Science, Massey University.

Nocek, J. E., and J. B. Russell. 1988. Protein and energy as an integrated system. Relationship of ruminal protein and carbohydrate availability to microbial synthesis and milk production. J. Dairy Sci. 71:2070-2107. https://doi.org/10.3168/jds.S0022 -0302(88)79782-9.

O'Brien, D., P. Brennan, J. Humphreys, E. Ruane, and L. Shalloo. 2014a. An appraisal of carbon footprint of milk from commercial grass-based dairy farms in Ireland according to a certified life cycle assessment methodology. Int. J. Life Cycle Assess. 19:1469-1481. https://doi.org/10.1007/s11367-014-0755-9.

O'Brien, D., J. L. Capper, P. C. Garnsworthy, C. Grainger, and L. Shalloo. 2014b. A case study of the carbon footprint of milk from high-performing confinement and grass-based dairy farms. J. Dairy Sci. 97:1835-1851. https://doi.org/10.3168/jds.2013-7174.

O'Brien, D., B. Moran, and L. Shalloo. 2018. A national methodology to quantify the diet of grazing dairy cows. J. Dairy Sci. 101:85958604. https://doi.org/10.3168/jds.2017-13604.

O'Callaghan, T. F., D. Hennessy, S. McAuliffe, K. N. Kilcawley, M. O'Donovan, P. Dillon, R. P. Ross, and C. Stanton. 2016. Effect of pasture versus indoor feeding systems on raw milk composition and quality over an entire lactation. J. Dairy Sci. 99:9424-9440. https://doi.org/10.3168/jds.2016-10985.

O'Donovan, M. 2016. Managing your grass. Pages 227-238 in Teagasc Dairy Manual. Teagasc.

O'Donovan, M., D. Hennessy, and P. Creighton. 2018. Ruminant grassland production systems in Ireland. Grassl. Sci. Eur. 23:17-25.

O'Donovan, M., and E. Kennedy. 2007. Using grass to reduce feed costs. Pages $63-80$ in Proceedings of Teagasc National Dairy Conference, Co. Kilkenny, Ireland. Teagasc.

O'Donovan, M., N. McHugh, M. McEvoy, D. Grogan, and L. Shalloo. 2017. Combining seasonal yield, silage dry matter yield, quality and persistency in an economic index to assist perennial ryegrass variety selection. J. Agric. Sci. 155:556-568. https://doi.org/10 .1017/S0021859616000587.

Ramsbottom, G., B. Horan, D. P. Berry, and J. R. Roche. 2015. Factors associated with the financial performance of spring-calving, pasture-based dairy farms. J. Dairy Sci. 98:3526-3540.

Shalloo, L. 2009. Pushing the barriers on milk costs/outputs. Pages 19-39 in Proc. Teagasc National Dairy Conference. Mullingar, Ireland. Teagasc.

Shalloo, L., P. Creighton, and M. O'Donovan. 2011. The economics of reseeding on a dairy farm. Ir. J. Agric. Food Res. 50:113-122. http: //hdl.handle.net/11019/55.

Shalloo, L., P. Dillon, M. Rath, and M. Wallace. 2004. Description and validation of the Moorepark dairy system model. J. Dairy Sci.
87:1945-1959. https://doi.org/10.3168/jds.S0022-0302(04)73353 -6 .

Stewart, A., and R. Hayes. 2011. Ryegrass breeding-balancing trait priorities. Ir. J. Agric. Food Res. 50:31-46.

Taweel, H. Z. 2007. Improving dry-matter intake of perennial-ryegrass pasture by dairy cows. Frontis 18:159-174. https://library.wur.nl/ ojs/index.php/frontis/article/view/1251.

Teagasc. 2014. Management Data for Farm Planning 2013/2014. Teagasc.

Teagasc. 2017. Pocket Manual for Reseeding. Teagasc. https://www .teagasc.ie/media/website/publications/2017/Reseeding-booklet .pdf.

Teagasc. 2021. Grass measurement. Accessed Jan.10, 2021. https:// www.teagasc.ie/crops/grassland/grass10/grass-measurement/.

Tozer, K., G. Rennie, W. King, N. Mapp, L. Aalders, N. Bell, D. Wilson, C. Cameron, and R. Greenfield. 2015. Pasture renewal on Bay of Plenty and Waikato dairy farms: Impacts on pasture performance post-establishment. N. Z. J. Agric. Res. 58:241-258. https://doi.org/10.1080/00288233.2015.1015742.

Tubritt, T. L. Delaby, T. Gilliland, and M. O'Donovan. 2020a. An investigation into the grazing efficiency of perennial ryegrass varieties. Grass Forage Sci. 75:253-265. https://doi.org/10.1111/gfs .12481

Tubritt, T., L. Delaby, T. J. Gilliland, and M. O'Donovan. 2020b. The relationship between the grazing efficiency and the production, morphology and nutritional traits of perennial ryegrass varieties. J. Agric. Sci. 158:583-593. https://doi.org/10.1017/ S0021859620000982.

Tuñon, G., E. Kennedy, B. Horan, D. Hennessy, N. Lopez-Villalobos, P. Kemp, A. Brennan, and M. O'Donovan. 2014. Effect of grazing severity on perennial ryegrass herbage production and sward structural characteristics throughout an entire grazing season. Grass Forage Sci. 69:104-118. https://doi.org/10.1111/gfs.12048.

VanRaden, P. 2002. Selection of dairy cattle for lifetime profit. Proc. 7th World Congr. Genet. Appl. Livest. Prod. 29:127-130. https //queries.uscdcb.com/publish/other/2002/submit_7wc_vanpaup .pdf.

Wilkins, P. W., and M. O. Humphreys. 2003. Progress in breeding perennial forage grasses for temperate agriculture. J. Agric. Sci. 140:129-150. https://doi.org/10.1017/S0021859603003058.

Wims, C. M., C. I. Ludemann, H. Phillips, and D. F. Chapman. 2017. The economic value to dairy systems of genetic gains in the nutritive value of perennial ryegrass in grass-clover pastures. Anim. Prod. Sci. 57:1357-1365. https://doi.org/10.1071/AN16487.

Wims, C. M., M. McEvoy, L. Delaby, T. M. Boland, and M. O'Donovan. 2013. Effect of perennial ryegrass (Lolium perenne L.) cultivars on the milk yield of grazing dairy cows. Animal 7:410-421. https:// doi.org/10.1017/S1751731112001814.

\section{ORCIDS}

T. Tubritt (ㄴ) https://orcid.org/0000-0002-6132-0484

L. Shalloo $\odot$ https://orcid.org/0000-0003-1714-672X

T. J. Gilliland (ํ) https://orcid.org/0000-0002-4514-1435 